\title{
Detection of Fusobacterium necrophorum and Dichelobacter nodosus from cow footrot in the Heilongjiang Province, China
}

\author{
Jiaqi Han, Jing Dong,Wenhui Yang, Yunze Xu, Qiming Xing, Yuelei Chen, Lin Li \\ Shenyang Agricultural University, College of Animal Science \&Veterinary Medicine, \\ The Key Laboratory of Zoonosis of Liaoning Province, Shenyang, China \\ Received February 13, 2018 \\ Accepted April 23, 2019
}

\begin{abstract}
Cow footrot in the Heilongjiang Province, northeast China is a problem resulting in lost production in agriculture. In this study, 200 swab samples from footrot lesions of naturally infected cows with odorous exudative inflammation and keratinous hoof separation at 10 farms were examined in the period from May 2016 to May 2017. Twenty cows from each farm were taken for sampling. The samples were examined for detectingthe presence of Dichelobacter nodosus (D. nodosus) and Fusobacterium necrophorum (F. necrophorum). Such detection was carried out using polymerase chain reaction (PCR). The PCR primers were designed to identify the $l k t A$ gene, which encodes a leukotoxin unique to F. necrophorum, and the fimA gene of D. nodosus. Of the 200 samples, $111(55.5 \%)$ revealed the presence of $F$. necrophorum and $11(5.5 \%)$ exhibited $D$. nodosus. The frequent finding of $F$. necrophorum in cow farms of Heilongjiang province, northeast China is noteworthy. The possibility of $F$. necrophorum and $D$. nodosusinfection should be an important concern when controlling cow footrot in China.
\end{abstract}

lktA, fimA, dairy farm, D. nodosus, F. necrophorum

Footrot is an acute, highly infectious disease of cattle caused by the synergistic action of several bacterial species. There are two species especially deserving attention: One is Dichelobacter nodosus (D. nodosus), which is the primary pathogen and essential transmitting agent in footrot (Kumaret al. 2016; Nielsenet al. 2016); the other is Fusobacterium necrophorum (F. necrophorum), which is required for D. nodosus to successfully initiate the infection (Zheng et al. 2016). These bacterial species are present in the rumen and faeces of normal cows and their environment (Tan et al. 1996; Nagaraja et al. 2005; Zhou et al. 2009). The primary aetiology for disease includes the virulence of the infecting $D$. nodosus strain and other factors, such as environmental conditions, the host's genetics, immunity, diet and stocking rates. Fusobacterium necrophorum has been suggested as a secondary pathogen in the disease development and could possibly increase its severity (Frosth et al. 2015; Çelebiand Otlu 2016).

Footrot is characterised by the presence of interdigital lesions, swelling, moderate to severe lameness, and a separation of the horny portions of the hoof from the sensitive tissues underneath (Agbajeet al. 2018; Best et al. 2018). It has a serious effect on the production performance of diseased cows. Since footrot was first reported by Adams in the Netherlands in 1960, many treatment and preventive measures have been developed for its control. However, the disease is common, with incidence rates in the range of $10-25 \%$ in many countries (Narayanan et al. 2003; Sun et al. 2009; Guo et al. 2010). Recently, the incidence of cow footrot has increased in the Heilongjiang Province in northeast China. The aim of the present survey was to determine the association between $F$. necrophorum and D. nodosus in cow footrot and to identify the role of the two bacterial species in the pathogenesis of this disease.

Address for correspondence:

Lin $\mathrm{Li}$

The Key Laboratory of Zoonosis of Liaoning Province

College of Animal Science \&Veterinary Medicine

Shenyang Agricultural University, Shenyang, China 


\section{Materials and Methods}

Collection of clinical samples

Two hundred foot swabs from cows showing the characteristic clinical sign of foot rot with odorous exudative inflammation and keratinous hoof separation were collected from 10 farms in the Heilongjiang Province, northeast China, from May 2016 to May 2017. Twenty cows were taken for sampling from each farm. One foot of each cow was sampled, and the samples were frozen at $-80^{\circ} \mathrm{C}$ until DNA was extracted using a sodium dodecyl sulphate (SDS)/phenol/chloroform method, as described previously (Zhou and Hickford 2000).

\section{Detection of F. necrophorum and D. nodosus}

Identification of $D$. nodosus and $F$. necrophorum was carried out using polymerase chain reaction (PCR) targeting the fimA and leukotoxin (lktA) genes. All the samples were subjected to the lktA gene amplification by PCR for the detection of F. necrophorum. The primer sequences were as follows: Forward, 5'-AATCGGAGTAGTAGGTTCTG-3'; Reverse, 5'-TCCAACAGAAACAGAAGCATC-3'. The PCR conditions consisted of an initial denaturation of $95^{\circ} \mathrm{C}$ for $5 \mathrm{~min}$, followed by 30 cycles of $94^{\circ} \mathrm{C}$ for $1 \mathrm{~min}, 53^{\circ} \mathrm{C}$ for $50 \mathrm{~s}$ and $72^{\circ} \mathrm{C}$ for $1 \mathrm{~min}$. This was followed by a final 10 -min extension at $72^{\circ} \mathrm{C}$. The $l k t A$ gene appears to be unique to F. necrophorum, as it is reportedly not present in other Fusobacterium species (Oelke et al. 2005). The partial DNA sequence of its $l k t A$ gene bears accession number AF_312861. The specificity of the lktA gene PCR was tested using bacterial DNA from the following species: Bacteroides nodosus, Bacillus welchii, Staphylococcus aureus, Escherichia coli andArcanobacterium pyogenes.

All the samples were subjected to fimAgene-specific PCR for detection of D. nodosus. The primer sequences were as follows: Forward, 5'-CGGGGTTATGTAGCTTGC-3'; Reverse, 5'-TCGGTACCGAGTATTTCTACCCAACACCT-3'. The PCR conditions consisted of initial denaturation at $95^{\circ} \mathrm{C}$ for $5 \mathrm{~min}$ followed by 30 cycles of $94^{\circ} \mathrm{C}$ for $1 \mathrm{~min}, 53^{\circ} \mathrm{Cfor} 50 \mathrm{~s}$ and $72^{\circ} \mathrm{C}$ for $1 \mathrm{~min}$. This was followed by a final 10 -min extension at $72^{\circ} \mathrm{C}$. The partial DNA sequence of the fim $A$ gene bears accession number AF 145217. The specificity of the fimA PCR was tested using bacterial DNA from the following species: Necrobacterium necrophorus, Bacillus welchii, Staphylococcus aureus, Escherichia coli and Arcanobacterium pyogenes.

\section{Statistical analysis}

The chi square $\left(\chi^{2}\right)$ test was performed to ascertain the association between $D$. nodosus and F. necrophorum in cow footrot.

\section{Results}

\section{Specificity of the lktA and fimA PCR}

Only F. necrophorum and D. nodosus produced a correct size amplification. (Figs 1 and 2).

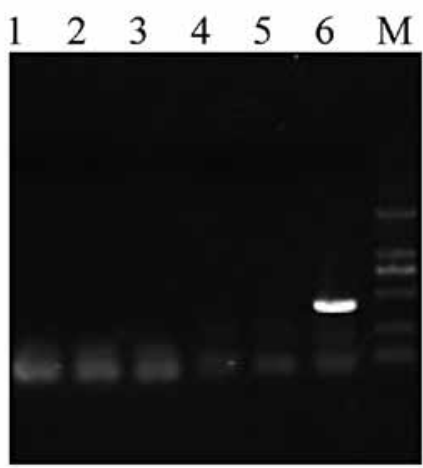

Fig. 1. Specificity of primers to amplify the lktA gene of $F$. necrophorum. Lane 1, 2, 3, 4, 5: PCR product of Bacteroides nodosus, Bacillus welchii, Staphylococcus aureus, Escherichia coli, Arcanobacterium pyogenes. Lane 6: PCR product of amplificate $F$. necrophorum DNA templates by primers (404 bp). M: DNA Marker DL2000 (2000 bp, 1000 bp, 750 bp, 500 bp, 250 bp, 100 bp).

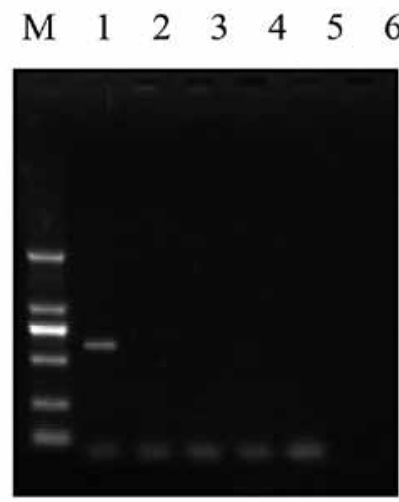

Fig. 2. Specificity of primers to amplify the fimA gene of $D$. nodosus. Lane 1: PCR Product of D. nodosus DNA templete by primer (621 bp). Lane 2, 3, 4, 5, 6: PCR product of Necrobacterium necrophorus, Bacillus welchii, Staphylococcus aureus, Escherichia coli, Arcanobacterium pyogenes DNA templates by primers. M: DNA Marker DL2000 (2000 bp, 1000 bp, 750 bp, 500 bp, 250 bp, 100 bp). 
Detection of F. necrophorum and D. nodosus

Of the 200 samples collected, $111(55.5 \%)$ revealed the presence of F. necrophorum and $11(5.5 \%)$ exhibited D. nodosus. Ten (5\%) showed the presence of both F. necrophorum and $D$. nodosus, while $101(50.5 \%)$ were positive for F. necrophorum alone and $1(0.5 \%)$ for $D$. nodosus only. Neither D. nodosus nor F. necrophorum was detected in 88 (44\%) samples (Table 1).

Table 1. The association of F. necrophorum and D. nodosus in cow footrot.

\begin{tabular}{lccc}
\hline & Negative for F. necrophorum & Positive for F. necrophorum & Total \\
\hline Negative for $D$. nodosus & 88 & 101 & 189 \\
Positive for $D$. nodosus & 1 & 10 & 11 \\
Total & 89 & 111 & 200 \\
\hline
\end{tabular}

\section{Discussion}

In this study, we have used a PCR approach for detecting two bacteria. Fusobacterium necrophorum has been reported to be associated with cattle lameness and other diseases (Berg and Loan 1975; Clark et al. 1985; Nagaraja et al. 2005). Dichelobacter nodosus, which is described as the most common cause of lameness in sheep (Moore et al. 2005), has been associated with cattle lameness for many years (Egerton and Parsonson 1966). Our survey's results are in agreement with the findings of previous researchers, who also reported detection of $D$. nodosus and F. necrophorum in similar proportions in cow footrot (Bennett et al. 2009).

In our study, few positive samples contained both bacteria, so it is not possible to conclude with certainty that both bacteria in combination are required for the manifestation of the disease. Nevertheless, F. necrophorum is believed to create an anaerobic microenvironment in hooves due to the necrosis it causes, thereby facilitating the establishment of D. nodosus followed by the development of footrot.

A longitudinal study reported that the F. necrophorum load was higher in the feet of sheep with severe footrot. The reason for this could be that $F$. necrophorum plays a vital role in creating the anaerobic microenvironment necessary for the establishment of $D$. nodosus in the infected hooves of sheep (Witco mb et al. 2014). This may also be the cause of footrot.

The detection of $F$. necrophorumin a large proportion of the cows and D. nodosus at a lower rate suggests that $D$. nodosus is not a major agent of cow footrot in the Heilongiiang Province, northeast China, while F. necrophorum could be a major agent of cow footrot. However, it does confirm that D. nodosus is present and able to persist on cow hooves, even if the farms are specialised cow farms that do not stock sheep.

As a consequence of the difficulty associated isolating and culturing F. necrophorum and $D$. nodosus, we used a PCR technique instead to detect these organisms and report the prevalence of these bacteria on cow hooves. The test results of the limited samples suggest that this technique will have a potential use in confirming the presence of $F$. necrophorum and $D$. nodosus in cows infected with footrot.

In conclusion, F. necrophorum is frequently found on the hooves of cows infected with footrot in the Heilongjiang Province, northeast China. Fusobacterium necrophorum and D. nodosus should be highly considered when controlling cow footrot in China.

\section{Acknowledgement}

This study was supported by the National Key Research and Development Program of China (Project No. 2017YFD0502200). 


\section{References}

Agbaje M, Rutland CS, Maboni G 2018: Novel inflammatory cell infiltration scoring system to investigate healthy and footrot affected ovine interdigital skin. Peerj 6:e5097

Bennett G, Hickford J, Zhou H 2009: Detection of Fusobacterium necrophorum and Dichelobacter nodosus in lame cattle on dairy farms in New Zealand. Res Vet Sci 87: 413-415

Berg JN, Loan RW 1975: Fusobacterium necrophorum and Bacteroides melaninogenicus as etiologic agents of foot rot in cattle. Am J Vet Res 36: 1115-1122

Best N, Gwozdz J, Suter R 2018: Direct serogrouping of Dichelobacter nodosus from Victorian farms using conventional multiplex polymerase chain reaction. BMC Res Notes 11: 108

Clark BL, Stewart DJ, Emery DL 1985: The role of Fusobacterium necrophorum and Bacteroides melaninogenicus in the aetiology of interdigital necrobacillosis in cattle. Aust Vet J 62: 47-49

Çelebi Ö, Otlu S2016: The isolation of Dichelobacter nodosus and identification by PCR from ovine footrot in Kars district, Turkey. Kafkas Univ Vet Fak Derg 22: 221-224

Egerton JR, Parsonson IM 1966: Isolation of Fusiformis nodosus from cattle. Aust Vet J 42: 425-429

Frosth S, Konig U, Nyman AK 2015: Characterisation of Dichelobacter nodosus and detection of Fusobacterium necrophorum and Treponema spp. in sheep with different clinical manifestations of footrot. Vet Microbiol 179: 82-90

Guo DH, Sun DB, Wu R 2010: An indirect ELISA for serodiagnosis of cattle footrot caused by Fusobacterium necrophorum. Anaerobe 16: 317-320

Kumar NV, Sreenivasulu D, Karthik A2016: Identification and characterization of Dichelobacter nodosus, serogroup $\mathrm{H}$ from ovine footrot in India. Anaerobe 40: 100-102

Moore LJ, Wassink GJ, Green LE 2005: The detection and characterisation of Dichelobacter nodosus from cases of ovine footrot in England and Wales. Vet Microbiol 108: 57-67

Nagaraja TG, Narayanan SK, Stewart GC 2005: Fusobacterium necrophorum infections in animals: pathogenesis and pathogenic mechanisms. Anaerobe 11: 239-246

Narayanan SK, Chengappa MM, Stewart GC 2003: Immunogenicity and protective effects of truncated recombinant leukotoxin proteins of Fusobacterium necrophorum in mice. Vet Microbiol 93: 335-347

Nielsen MW, Strube ML, Isbrand A2016: Potential bacterial core species associated with digital dermatitis in cattle herds identified by molecular profiling of interdigital skin samples. Vet Microbiol 186:139-149

Oelke AM, Nagaraja TG. Wilkerson MJ 2005: The leukotoxin operon of Fusobacterium necrophorum is not present in other species of Fusobacterium. Anaerobe 11: 123-129

Roberts DS, Egerton JR 1969: The aetiology and pathogenesis of ovine foot-rot: II The pathogenic association of Fusiformis nodosus and F.necrophorus. J Comp Pathol 79: 227-226

Sun DB, Wu R, Li GL 2009: Identification of three immunodominant regions on leukotoxin protein of Fusobacterium necrophorum. Vet Res Commun 33: 749

Tan ZL, Nagaraja TG, Chengappa MM 1996: Fusobacterium necrophorum infections: virulence factors pathogenic mechanism and control measures. Vet Res Commun 20: 113-140

Witcomb LA, Green LE, Kaler J 2014: A longitudinal study of the role of Dichelobacter nodosus and Fusobacterium necrophorum load in initiation and severity of footrot in sheep. Prev Vet Med 115: 48-55

Zheng J, Sun L, Shu S 2016: Nuclear magnetic resonance-based serum metabolic profiling of dairy cows withfootrot. J Vet Med Sci 78: 1421-1428

Zhou H, Hickford JGH 2000: Extensive diversity in New Zealand Dichelobacter nodosus strains from infected sheep and goats. Vet Microbiol 71: 113-123

Zhou H, Bennett G, Hickford JG 2009: Variation in Fusobacterium necrophorum strains present on the hooves of footrot infected sheep goats and cattle. Vet Microbiol 135: 363-367 